Discussion Paper No. 03-01

\title{
Lead Markets of Environmental Innovations: A Framework for Innovation and Environmental Economics
}

Marian Beise and Klaus Rennings

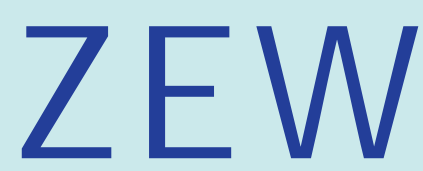

Zentrum für Europäische Wirtschaftsforschung $\mathrm{GmbH}$

Centre for European Economic Research 
Discussion Paper No. 03-01

\section{Lead Markets of Environmental Innovations: A Framework for Innovation and Environmental Economics}

Marian Beise and Klaus Rennings

Download this ZEW Discussion Paper from our ftp server:

ftp://ftp.zew.de/pub/zew-docs/dp/dp0301.pdf

Die Discussion Papers dienen einer möglichst schnellen Verbreitung von neueren Forschungsarbeiten des ZEW. Die Beiträge liegen in alleiniger Verantwortung der Autoren und stellen nicht notwendigerweise die Meinung des ZEW dar.

Discussion Papers are intended to make results of ZEW research promptly available to other economists in order to encourage discussion and suggestions for revisions. The authors are solely responsible for the contents which do not necessarily represent the opinion of the ZEW. 


\section{Non-technical summary}

Environmental regulations often want to stimulate the generation and adoption of eco-efficient innovations. An important argument in the public debate is also the creation of new markets for environmentally benign products, processes and services that other countries adopt and therefore generate export opportunities for the pioneering country. The research so far concentrated on the question how national environmental regulation can induce innovations. The question addressed in this paper is whether environmental regulations can create lead markets, enabling local firms to export innovations that are induced by local market conditions and national regulations. We identify relevant factors for lead markets of environmental innovations: price advantages, demand advantages, transfer advantages, export advantages and strict regulation (Porter-effect).

The approach is applied to two case studies: fuel-efficient passenger cars and wind energy. In both cases, one country adopted the innovation firstly. Later, other countries followed the same innovation design favoured by the lead market. The lead market became a large exporter in the wind generation and car industry respectively. We discuss the regulations employed and the reasons for the international success of the innovations induced by them.

We draw some conclusions concerning the relevance of our identified lead market factors for the two cases. Price advantages seem to be a relevant albeit not dominating driver of the international diffusion of the innovation in both cases. Demand advantages are crucial for the lead market of fuel-efficient cars since other criteria of global demand are still more important than environmental criteria. Transfer advantages can be identified in both cases since the R\&D activities of the German automobile firms and the respective efforts of the Danish wind industry are intensively watched by other countries. Export advantages address the similarity of market conditions at home and abroad. They are more important in the wind energy case than for fuel-efficient cars. Finally the market structure or Porter effect has proved to be relevant in both cases. In the case of wind energy strict regulation, together with an anticipated regulatory trend as described above, can be seen as the dominating success factor for Denmark as a lead market. Without strict regulations and international policy diffusion renewable energies would not be competitive. For fuel efficient cars the Porter effect is less important since environmental regulation is to date still outweighed by consumer preferences that steer diametrically into the opposite direction.

Summing up, all lead market factors seem to be at least relevant for environmental innovations. The importance of the Porter effect depends on its relation to global demand and regulatory effects. If national regulation is supported by global demand or regulatory trends, a strong effect can be identified, as was shown in the cases of wind energy in Denmark and Diesel-High-pressure-direct-injection in Germany. If it is not supported, the market remains idiosyncratic, as could be seen in the failure of the the Golf Ecomatic. 


\title{
Lead Markets of Environmental Innovations:
}

\section{A Framework for Innovation and Environmental Economics*}

\author{
Marian Beise and Klaus Rennings \\ Centre for European Economic Research (ZEW) \\ P.O.Box 103443, D-68034 Mannheim, Tel: +49/621/1235-207, Fax: +49/621/1235-226 \\ E-mail: rennings@zew.de
}

\begin{abstract}
Environmental regulations often want to stimulate the generation and adoption of ecoefficient innovations. An important argument in the public debate is also the creation of new markets for environmentally benign products, processes and services that other countries adopt and therefore generate export opportunities for the pioneering country. The research so far concentrated on the question on how national environmental regulation can induce innovations. The question addressed in this paper is whether environmental regulations can create lead markets, enabling local firms to export innovations that are induced by local market conditions and national regulations. We identify relevant factors for lead markets of environmental innovations.
\end{abstract}

So far, the lead market concept in innovation economics has only been applied to innovations in general. We extend the lead market model to environmentally friendly innovations, considering their peculiarities, in particular the public good character of environmental benefits and the role of regulations. The approach is applied to two case studies: fuel-efficient passenger cars and wind energy. In both cases, one country adopted the innovation first. Later, other countries followed the same innovation design favoured by the lead market. The lead market became a large exporter in the wind generation and car industry respectively. We discuss the regulations employed and the reasons for the international success of the innovations induced by them. We find that strict regulation has created lead markets when it was supported by a global demand or regulatory trend.

Keywords: Lead markets, technological progress, environmental innovation, wind energy, fuelefficiency

\footnotetext{
* This paper results from the research project "Policy-Frameworks for the Development of International Markets for Innovations of a Sustainable Economy - from Pilot Markets to Lead markets" funded by the German Federal Ministry of Education and Research (BMBF) under the Research Initiative "Sustainability and Innovation - Frameworks for Innovation towards Sustainability". We are grateful for helpful comments from our project partners Martin Jänicke, Klaus Jacob, Dietmar Edler, Jürgen Blazejczak, Ulrich Petschow and Thomas Loew, and for technical support from our research assistants Ilja Karabanow and Sarah Gramm.
} 


\section{Introduction}

The relationship between innovation and the environment has received increasing attention in recent years (OECD 2000). Eco-innovations are regarded as an important mean of solving a country's ecological problems without reducing the economic activity that causes the ecological problem (see Klemmer 1999, Rennings 2000, Hemmelskamp et al. 2000). Special attention is paid to the dynamic process of technological change and how regulations can induce environmentally friendly innovations with export potentials for the domestic industry (Jaffe, Newell and Stavins 2002). Thus governments increasingly attempt to actively support the generation and adoption of eco-innovations.

However, there are two fundamental problems with this export oriented environmental policy pproach. First, policy makers may be frustrated by reviewing the respective literature discussing the general relationship between regulation and innovation. Regulations are often seen as an obstacle for innovators, and economists commonly postulate deregulation and competitive markets a more conducive environment for innovations than governmental restrictions (Dosi et al. 1990, Porter 1990). Yet, these conclusions have been drawn for common markets with private goods. In cases of market failure, e.g. when technological external effects can be identified as in the case of environmental innovations, it is doubtful whether a strategy based on competitive markets without regulation is sufficient.

Second, regulation is likely to induce specific innovation designs that are not profitable to adopt in countries where the same regulation is not in place. While there is little doubt about the positive effect of new technologies on environmental problems, the relationship between innovations, induced by national regulation, and exports is ambiguous. Innovations can only be exported when users in other countries have an incentive to adopt the same innovations. On average, a positive effect of innovations on export performance is empirically supported on a micro-economic level (Ebling and Janz, 1999). However, many innovations that are successful at home cannot be successfully exported. It is reasonable to assume that local, context-specific innovations are less appealing to users abroad. If innovations are specific to local environmental conditions, their added value is restricted to the special conditions of one or a few countries. This can also be the case for innovations induced by regulation. If innovations are only generated in order to meet a very specific national regulation, there is little incentive for firms to follow in countries that do not adopt the same regulation. A certain empirical evidence for the hypothesis that regulation-induced innovations are less likely to diffuse internationally can be seen in the fact that culture-specific and regulated industries have below average export-shares. Examples are food and often state-owned industries such as energy, telecommunications (until the 1990s), health or environmental goods and services.

One possible argument for environmental lead markets is the thesis of Porter and van der Linde (1995). They suggest that strict environmental regulations can push local firm's innovativeness bwards increased resource efficiency so that the innovations are profitable even if foreign countries do not adopt the regulation. Another internationalisation mechanism is the international policy conver- 
gence, i.e. the adoption of the same environmental regulation worldwide. If other countries adopt the same script of regulation, demand emerges for the same environmental technology in these countries, too. This paper discusses these and other mechanisms leading to the worldwide adoption of innovations responding to national environmental regulations.

The paper is structured as follows: In section 2 we present a general model of lead markets developed by Beise (2001). In section 3 we extend this model to eco-innovations, considering their peculiarities, and develop a framework for further analyses. Due to the peculiarities of eco-innovations we identify environmental regulations and policy diffusion as key lead market factors. In section 4 , two casestudies are analysed with the derived framework: the emergence and international diffusion of wind energy generation and fuel efficient technologies for passenger cars. Section 5 draws some conclusions.

\section{How can national regulation induce global innovations?}

\subsection{A model for the international diffusion of innovations}

A first step in analysing the international success of eco-innovations and the respective policies is to study the determinants of the international diffusion of non-environmental innovations. Looking at the diffusion of globally successful innovations, one can observe, that many innovation designs became internationally successful after they have been preferred and adopted by a single country. The facsimile machine, for instance, was adopted in Japan before it became the globally preferred design for textbased telecommunication. Cellular phones were widely adopted in the Nordic countries first and the US led the adoption of the personal computer. The leading user country normally stays ahead in the penetration rate for a long time, supplying the firms with long-term user feedback and market knowledge, enabling them to constantly improve the innovation and remain in the lead. Figure 1 exhibits the typical international diffusion pattern of a specific innovation design. Countries that are first in adopting an internationally successful innovation can be called lead markets, the following countries the lag markets. 


\section{Figure 1: The international diffusion pattern of an innovation design}

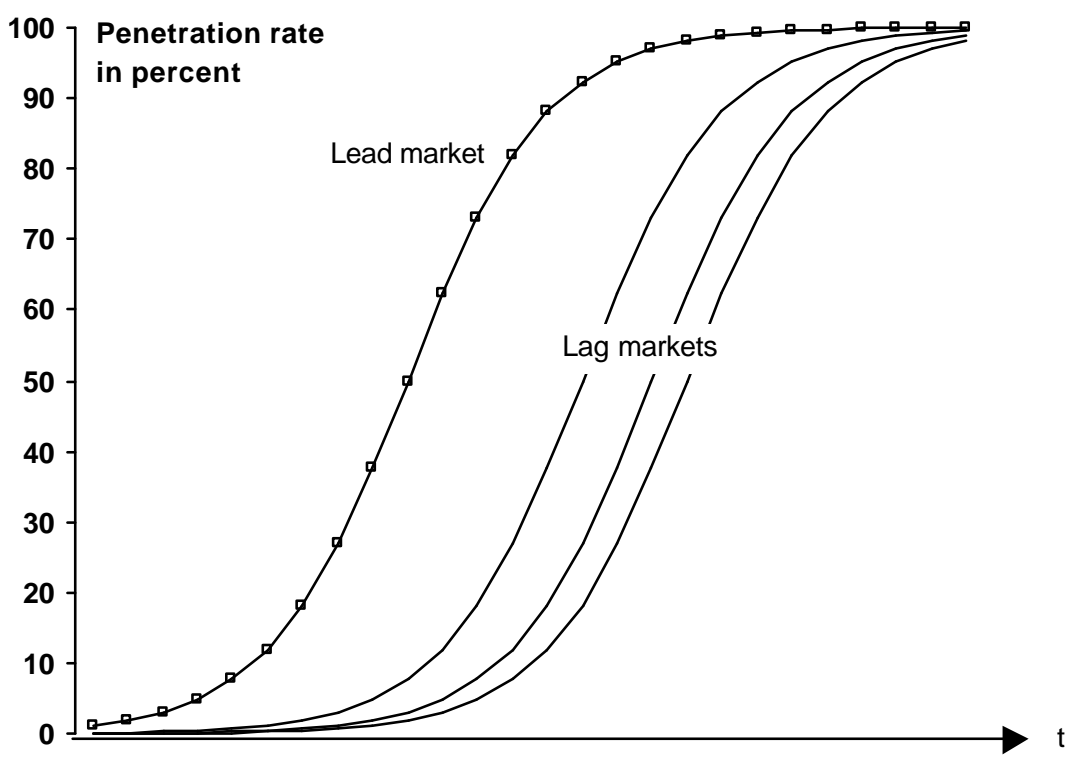

Differences between lead and lag markets cannot simply be answered with reference to a lesser degree of "innovativeness" in the lagging countries. While export success of a country's firms has previously been explained mostly by leads in technological knowledge, demand and market conditions that lead to an early adoption of innovations are vital factors for the international competitiveness of countries as well (see Porter, 1990). Historic studies of globally successful innovations such as Vernon (1966), Franko (1976), Tilton (1971) and several of the case studies collected in Mowery, Nelson (1999) have indeed found that the origin of the international competitiveness of a country is a demand gap and that this demand gap has caused the technology gap observed after the product became established worldwide. ${ }^{1}$ The technological gap is based mainly on experience in production (learning-by-doing) and usage (learning-by-using). In contrast, discoveries and inventions often occurred in countries other than the country where the innovation was first widely adopted. There, firms could usually use technical knowledge from abroad to match local demand.

Lead markets are countries that adopt successful innovations quickly, despite the fact that they did not necessarily invent the technology. Frequently, users in other countries have adopted rival innovation designs before which never became a success abroad. But only the innovation design adopted in the lead market becomes adopted in other countries and finally supersedes designs previously preferred in other countries. For instance, the telex system was adopted before the market breakthrough of the facsimile machine hit the road; in France the online-service "Minitel" similar to the Internet was adopted

\footnotetext{
${ }^{1}$ Local firms profit more from domestic users that demand innovations earlier than other users, because they perceive local demand preferences earlier and user-producer interaction is more efficient within countries. This is the home market advantage of firms, first suggested by Linder (1961) and later refined by Lundvall (1988). In management science, customer interaction has been identified as one of the most important success factors of innovation, see e.g. Cooper, Kleinschmidt (1987).
} 
in the early 1980s before the Internet took off in the United States. This illustrates, that innovations that have been successful in their home countries have to compete on the world market against other innovation designs that are favoured by other countries due to their specific environment or market conditions.

The introduction of competing innovation designs is a factor for understanding why the early adoption of an innovation in one country sometimes leads to an export success and sometimes not. An innovation design is a specification or configuration of an innovation idea. Different designs of an innovation fulfil the same function but can have different modes or specifications (see Utterback, 1994: 18). For instance, an IBM, an Apple Macintosh or a Sinclair computer are different designs of a personal computer. The GSM cellular telephone, personal satellite telephony and pagers are different designs of mobile communications. A dominant design is defined as a design that is adopted by a majority of users, a design that wins the "allegiance of the marketplace" (Utterback, 1994: 24). A globally dominant design is the design that is adopted by most countries, in contrast to nationally dominant designs, that are only widely adopted within one country.

Lead markets are countries that first adopt a globally dominant innovation design; they lead the international diffusion of an innovation and set the global standard. For instance, the mass market for cellular mobile telephony emerged in the Nordic countries before a joint-European cellular system became the world standard in mobile telephony. And parallel with the United States leading the usage of PCs the IBM-Microsoft-Intel specification prevailed on the world market as the global dominant design of personal computers. On the other hand, several innovation designs became widely adopted in one country but never became an export success and even squeezed out of their home market years later by a global dominant design. Countries that are early adopters of an innovation design that is not adopted by other countries can be called idiosyncratic markets. A firm responding to this idiosyncratic demand can achieve temporary innovation success in these local markets but later has to switch to the dominant design, thus losing its pioneer advantages. Figure 2 includes the penetration rates of a competing innovation design that was initially adopted by a lag country that switched to the lead market design later. This pattern shows that lead markets are not necessarily the most innovative markets. 
Figure 2: The international diffusion pattern of competing innovation designs

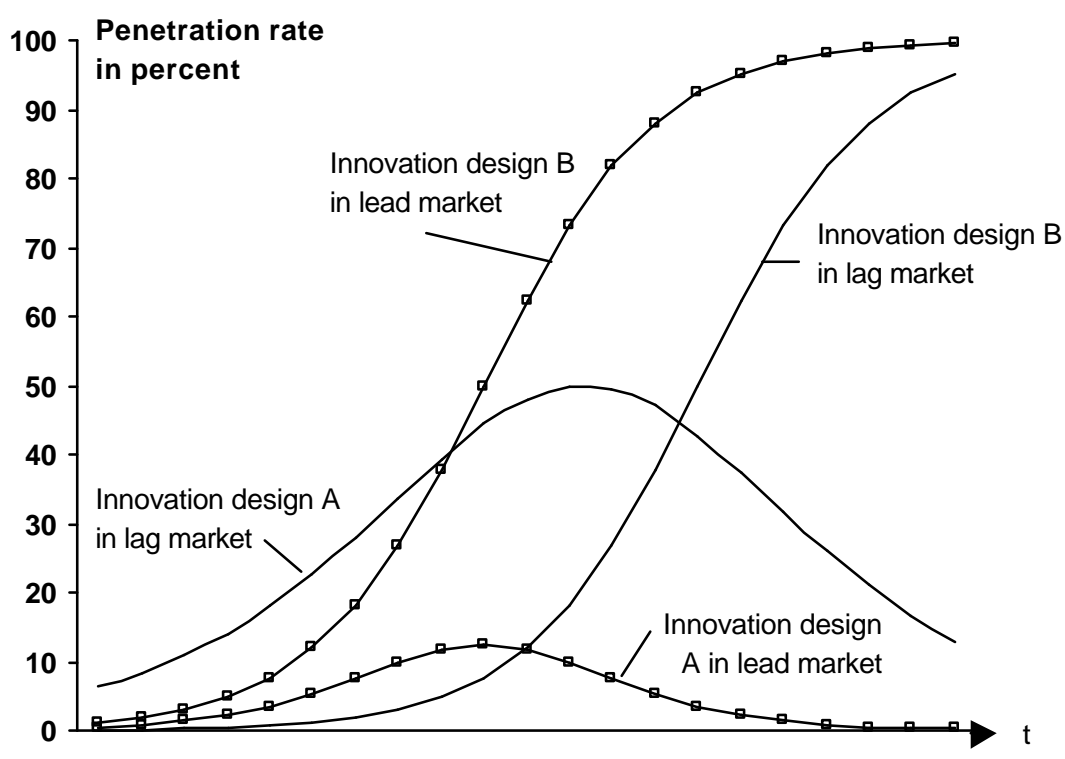

\subsection{Lead market factors}

Beise (2001) has identified a typology of five basic groups of advantages of a lead market. The five lead market factors are as follows:

- the price advantage,

- the demand advantage,

- the transfer advantage,

- the export advantage and

- the market structure advantage.

A price advantage arises from national conditions that result either in relative price decreases of a nationally preferred innovation design compared to designs preferred in other countries or in anticipation of international factor price changes. Countries can gain a price advantage if the relative price of the nationally preferred innovation design decreases so that differences in demand preference to foreign countries can be compensated. This price mechanism is the centrepiece of Levitt's (1983) globalisation hypothesis, according to which the consumers in foreign markets "capitulate" to the attraction of lower prices and abandon their initial endowments of goods. Price reductions are mainly due to cost reductions based on static and dynamic economies of scale. Nation-specific factors of economies of scale are market size and market growth. Another price advantage emerges from anticipatory factor prices: the lead market demands innovations that are induced by factor price changes which later occur globally. 
Demand advantages are caused by national conditions resulting in the anticipation of the benefits of an innovation design emerging at a global level. A good example are off-grid solutions in the energy and telecommunication sector. Such innovations are more beneficial and thus more likely to be adopted first in industrialised countries with large landscapes and a low population density, as e.g. Scandinavia. When other countries catch up, they demand the same innovation that was already used in the country at the forefront of the trend. Another example are trends related to environmental problems such as climate change. Some countries suffer more from the risks of rising temperatures (e.g. countries with above average risks of flooding like the Netherlands) than others and will thus anticipate this trends earlier.

Transfer advantages are national conditions that increase the perceived benefit of a nationally preferred innovation design for users in other countries or by which national demand conditions are $\mathfrak{x}$ tively transferred abroad. The perceived benefit increases when information on the usability of the innovation design is made available. The first adoption of an innovation of unknown merit reduces the uncertainty and therefore the risk for subsequent adopters initiating a bandwagon effect. This is also called the demonstration effect of adoption (Mansfield, 1968). A country can have a transfer advantage if its market context supports increases in the perceived benefit of a nationally preferred innovation design for users in foreign countries. Diffusion theory suggests that the international diffusion of durable goods depends on the intensity of communication between two countries (Takada and Jain, 1991). The lead market could therefore be the country that has the strongest communication ties with other countries.

Conditions that support the inclusion of foreign demand preferences in nationally preferred innovation designs constitute a national export advantage. One can derive three factors of a national export advantage: domestic demand that is sensitive to the problems and needs of foreign countries, long-time export experience of domestic firms and the similarity of local market conditions to foreign market conditions. Dekimpe et al. (1998) support the hypothesis already suggested by Vernon (1979) that the higher the similarity of cultural, social and economic factors between two countries, the greater the likelihood that an innovation design adopted by one of two countries will be adopted by the other country as well.

The market structure effect focuses mainly on the degree of competition. Competition and entrepreneurial effort has been described as one of the main determinants of international patterns of innovations from Posner (1961) to Dosi et al. (1990). A lead market is commonly a highly competitive market. This is due to the fact that faster development and more market-oriented innovations can be supported by competitive market structures. First of all, buyers tend to be more demanding when they face competition than when they are tightly regulated or hold a monopoly (Porter, 1990). Second, competing firms are more strongly pressurised to follow those who have already adopted a new technology (Mansfield, 1968). Third, and maybe most importantly, more innovation designs are tested in a 
competitive market than in a monopolised market. In the absence of barriers to entry or the contestablility of markets (i.e. firms can enter and exit a market, see Baumol, Panzar, Willig, 1982) new products and technologies are frequently brought about by new firms (see e.g. Audretsch 1995). This makes the process more efficient in finding the best product by means of search and selection, i.e. the product that is most profitable for the user and thus the dominant design. As a result, a competitive market is more appropriate to find a design that is not only the best within the domestic environment but also the better in each national contexts than the locally selected designs. The more innovative climate of one market compensates for the international differences. This notion of competitive markets as more innovative markets is even found to be correct in the case of Japan's international success, which was long time suspected of being based on protectionism and interventionism: "Its [Japans] industries succeed not when the government manages competition but when it allows competition to flourish." (Porter et al. 2000).

\section{Extending the lead market model to eco-innovations}

\subsection{Peculiarities of eco-innovations: the double eternality problem}

Applying the lead market model to environmental innovation, certain peculiarities have to be considered. We use the following definition of environmental innovation or eco-innovation (Rennings 2000, Rennings and Zwick 2002): Environmental innovations consist of new or modified processes, techniques, practices, systems and products to avoid or reduce environmental harms. Environmental innovations may be developed with or without the explicit aim of reducing environmental harm. They also may be motivated by the usual business goals such as reducing costs or enhancing product quality. Many environmental innovations combine an environmental benefit with a benefit for the company or user. Eco-innovations produce positive spillovers in both, the innovation and diffusion phase. Positive spillovers of R\&D activities can be usually identified for all kinds of innovations. The peculiarity of eco-innovations is that positive spillovers appear also in the diffusion phase due to a smaller amount of external costs compared to competing goods and services on the market. This peculiarity of ecoinnovations has been called the double externality problem (Rennings 2000).

Due to be problem of double externalities, eco-innovating firms face the problem that they produce a public good, at least to a certain degree, depending on the character of the good. While for instance biological food creates benefits for both the user (taste, health) and the environment (less pesticides) compared to the consumption of conventional products, the benefits of other environmental goods and services such as electricity from renewable energy have no additional private benefits compared to the use of fossil or nuclear energy. Thus the double externality problem reduces the incentives for firms to invest in eco-innovations. Therefore a need can be identified for measures of environmental and innovation policy. A pure strategy of deregulation and creation of competitive markets is not able to correct these market failures. As long as markets do not punish environmentally harmful impacts and 
reward environmental improvements, competition between environmental and non-environmental innovation is distorted. This would also mean that only the international diffusion environmental regulations strengthens the adoption of new environmental technologies abroad, which can therefore be identified as a key success factor of lead markets for environmental innovations.

On the contrary, Porter and van der Linde (1995) argue that even in the absence of policy diffusion strict regulations can put additional pressure on firms to innovate in eco-efficient technologies, and this may improve the competitiveness of domestic firms. The logic behind this is that efficient use of natural resources is at least partly a private good since firms have to pay for the use of water, production of waste etc. Thus natural resource efficiency can be regarded as a part of the total efficiency and competitiveness of a firm. The Porter hypothesis implicitly argues that innovation offsets of environmental policy can occur in two ways:

Case A): Advantages in the short run occur, provided that natural resources are private goods, as in the above mentioned case of biological food that was mentioned above. Another example is the rational use of water, energy and material reducing the bills for electricity, water or waste. In case A the double externality problem is thus not relevant, or even if it is relevant it may be possible to find opportunities for environmental improvements at zero costs. The hypothesis assumes that regulatory pressure triggers firms to develop innovations with win-win-opportunities that they have not seen before due to Xinefficiencies, bounded rationality or incomplete information. While this hypothesis is theoretically valid, it's relevance concerning the magnitude of such win-win-potentials is still controversial (Jaffe, Newell and Stavins 2002).

Case B): Advantages occur in the long run when natural resources have an adequate market price, depending on the international diffusion of environmental policy measures. Case B considers the problem of double externalities. Without policy diffusion the pioneering country has to bear additional costs and a loss of competitiveness.

We assume case B to be typical for eco-innovations. As far as eco-innovations have the character of case A, they do not differ from other innovations. Lead markets for innovations of type A are siumilar to the argumentation of the market structure effect described above. The difference is that, here, the incentives to innovate are not generated by competition but by regulation. For eco-innovations the market structure effect becomes the Porter effect. For the case B innovations the international diffusion of regulation must be added to the lead market model.

\subsection{Cross-national policy diffusion}

It can be preliminarily concluded that the adoption of national regulations by other countries is one main driver for the international diffusion of environmental innovations. Thus it is important to understand, why environmental regulations from pioneering countries are adopted by other countries and diffuse around the world, ensuring the adoption of the same innovation design internationally. Policy 
convergence, as discussed among policy analysts, is the frequently observed convergence of policy instruments or policy content, i.e. the institutional tools available for administering policy (Bennett 1991, p. 218), across administrative borders. We argue in this paper that the motivations of governments to adopt a foreign policy or regulation can be explained by principles similar to the factors governing the diffusion of innovations as presented above.

One process of policy convergence is the cross-national diffusion of policies, the pattern of successive adoption of a policy innovation by imitation. A new policy can be called a policy innovation and the adoption of a specific policy by most countries worldwide an international diffusion of policy innovations (Bennett 1991, Kern et al. 2000). Cross-national policy diffusion can explain the international diffusion of technical innovation designs as well. New regulations of national governments can induce innovations for instance if they require the adoption of new technologies, change relative factors costs or in general change the relative benefits of different designs. If one country introduces a new regulation that induces innovations or spurs the adoption of a specific innovation design, this innovation design will be adopted by users in other countries as well, if other countries introduce this same regulation. The international diffusion of policies in a broad range of fields has already been studied, for example with regard to bureaucratic accountability (Bennett 1997), administrative reform (Peters 1997) and most notably to environmental regulations (see Kern et al. 2000, Jänicke 2000).

Kern et al. (2000: 509) observe the same phenomenon that was to be seen in the international diffusion of innovations: Despite the fact that countries differ in conditions such as ecological problems, equiring different policy instruments, these countries often adopt the same regulations, even down to the wording used by an other country (Bennett 1991: 222). Some countries "sacrifice...autonomy to avoid unnecessary cross-national divergence" (Bennett 1991: 227). If it is more likely that policy makers follow a certain country, this country has an international advantage comparable to the transfer advantage that is discussed in lead market theory. Leading countries are those that are generally more watched by many other countries.

In reviewing the literature of cross-border policy convergence, Bennett (1991) and Dolowitz, Marsh (1996) describe policy internationalisation mechanisms that are analogous to the transfer mechanisms constituting the diffusion of technical innovations. First of all, social problems and policy instruments intended to ease these problems are surrounded by uncertainty. The introduction of regulations offers a test of effectiveness and reduces uncertainty (lesson drawing). ${ }^{2}$ Obviously, countries adopt foreign policies that proved to be effective in one country without harming that country's economy. ${ }^{3}$ For in-

\footnotetext{
2 "Uncertainty about the cause of problems, the effects of previous decisions or the future causes actors to search for policies they can borrow” (Dolowitz and Marsh, 1996: 347).

${ }^{3}$ Effective regulation in turn can lead to the fear of political actors in other countries of falling behind its competitors triggering the adoption of the same policies (Dolowitz and Marsh, 1996: 349). However, foreign policies
} 
stance, deregulation in the telecommunications industry in the United States brought down the price of telephone calls. This led governments of many other countries to deregulation of the telecom sector as well. ${ }^{4}$

Policy communities as well as international organisations such as the OECD, the WTO and transnational professional organisations (e.g. aviation, telecommunication, etc.) share experience and have an incentive to harmonise policies among countries, most notably if countries' policies are interdependent, and taking so-called best practises as a guidance. In keeping with the transfer effect of multinational firms, international organisations such as NGOs (Non-governmental organisations) can apply pressure to (or convince) governments worldwide to adopt a specific policy. For instance Greenpeace has transferred the policy of chlorine-free paper worldwide (Sonnenfeld 2000). Furthermore, it has been argued that governments of large countries can force other governments to introduce a specific regulation, for example this international transfer process is suggested to had have happened to in the case of anti-cartel laws in Europe (Majone 1991), deregulation of telecommunication (Hills 1986) or by the regulatory requirements of the IMF for the granting of loans (Dolowitz and Marsh 1996: 348).

It has been observed that some countries' policies are more likely to be copied than others, for instance the United States and Germany (Dolowitz and Marsh, 1996: 352). Yet, political science literature offers little nation-specific characteristics of these regulatory leaders. ${ }^{5}$ However, the theoretical incentives behind adopting a similar regulation are already mentioned earlier in this chapter: risk reduction, global externalities and other incentives of multinational organisations to harmonise international conditions and the international reputation and attention a country receives. Thus, a country is more likely to be followed in the adoption of specific policy instruments if it lowers risk most visibly, draws most international attention, spreads political ideas internationally, has more power in international organisations and has a good reputation on a political rather than technical level. As well, and in line with the argument of the next section, the more ideological and institutional similarities a country has to other countries, the more support the international transfer of domestic policies receives (Dolowitz and Marsh 1996: 353).

\subsection{Extending the lead market model to environmental innovations}

An extension of the lead market model to eco-innovations should consider both the common internationalisation factors of the lead market model and the double externality problem, taking into account

\footnotetext{
not only 'draw lessons' but also legitimate conclusions already reached domestically and are taken to put pressure on the domestic legishation process (Bennett, 1991: 223).

${ }^{4}$ A detailed but rather disapproving assessment of the international adoption of telecom deregulation policies initiated by the United States is suggested by Hills (1986).

${ }^{5}$ Rather, the characteristics of political instruments that are more transferable internationally are offered for example by Rose (1993).
} 
the prominent role of policy and it's international diffusion. Figure 3 shows the relationships between the different levels.

Policy patterns consist of instruments such as emission control legislation, tax regimes or subsidies for specific technologies. However, the relationship between politics and innovations is not purely instrumental as most economist want to believe. Policy styles can influence the real effects of instruments (Richardson 1982, Jänicke 2000). For instance, a consents-oriented, calculable and flexible style has been suggested to be more innovation effective than other styles (Blazejczak et al. 1999). A policy pattern has a direct influence on the willingness to adopt innovations. This relationship is marked with (1) in the figure. The policy level looks at the likelihood that innovations occur at all. It does not explain under which circumstances an international diffusion of innovations or regulations occurs. Therefore, additional factors have to be considered. The second level of the model constitutes the internationalisation factors. A further analysis should reveal, whether policy styles have an influence on the internationalisation of innovations via the internationalisation of policy instruments (marked as (2) in Figure 3). Yet, policy makers are not the only actors on the policy level. Transnational and nongovernmental organisations such as the OECD, the United Nations, the WTO, Greenpeace and other pressure groups are spreading environmental policy discussions around the world and facilitate the international harmonisation of policies. These international organisations indirectly and even directly support the standardisation of eco-innovations as well. The export advantage of lead markets that was described above is often constituted by national institutions such as banks, suppliers and customers pressing firms to develop innovations that can be exported. Institutions can have the opposite effect as well. For instance, state-owned monopolies such as telecom and public transport companies often demand nation-specific technologies that do not match the requirements of the world market. Finally, multinational firms - as discussed above - have an incentive to standardise their technology within their global network of affiliates instead of employing different technologies from country to country. Thus they try to push suppliers as well as policy makers to accept - or more often wait for international agreements on environmental regulations. 
Figure 3: A framework for analysing the international diffusion of eco-innovations

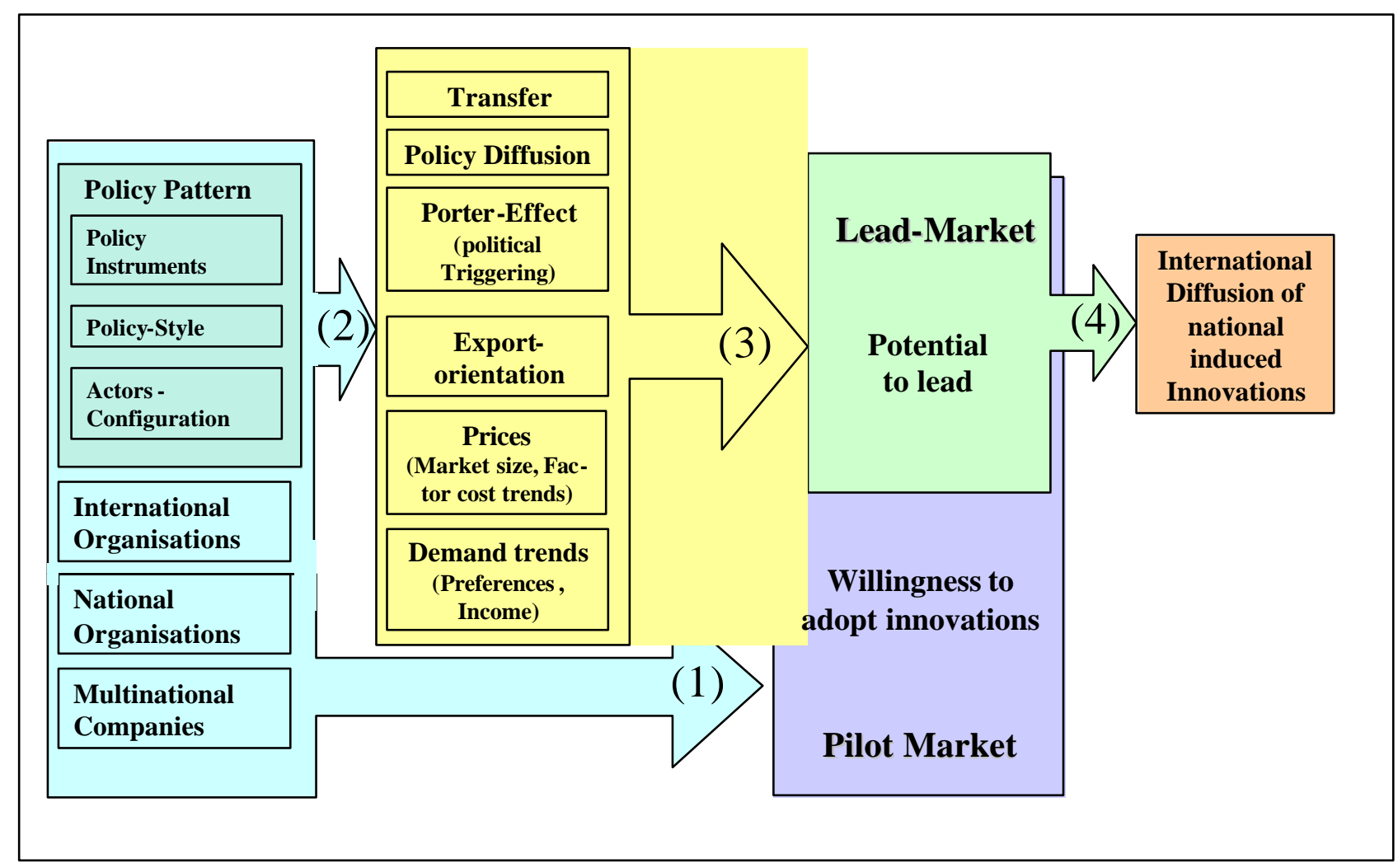

The discussion on the internationalisation of eco-innovations above has shown that environmental policy-specific arguments can in principle be assigned to the five lead market factors envisioned in innovation economics and described in section 2.2.

The market structure advantage, however, that focused on competition as the most important factor to push innovations in the conventional lead market model, has been interpreted in the context of environmental innovations as the "Porter effect". In our context the "Porter effect" specifically considers the problem of double externalities (described as case B in section 3.1). Environmental problems can not be solved simply by deregulation strategies, since the existence of negative external effects requires regulatory measures correcting these market failures. We argue therefore that the market structure advantage shall include the "Porter effect", understood as strict regulation for the respective environmental problem in the lead country. Strict environmental policy can induce innovations, but without policy diffusion the pioneering country has to bear additional costs and a loss of competitiveness in the long run.

The fact that policies are diffusing between nation states or are harmonised in international organisations can provide an additional factor for the internationalisation of innovations. Those countries, that are considered pace makers in the development of environmental policy, do have a transfer advantage. 
This position might be gained either by innovativeness or a strong position in international organisations.

For the further analysis of lead markets for eco-innovations, the framework as illustrated in Figure 3 will be used including both, the modified lead market attributes of countries and the relationship between the policy level and the national adoption of innovations. The traditional impact of policies on the adoption of innovations in a country (1) is not sufficient for making the distinction between lead markets and idiosyncratic national markets. This can be achieved by including the modified lead market factors (2). The analysis within innovation economics has been focused on the relationship between the lead market factors and the potential of a country to lead the adoption of a specific innovation design internationally (3). These factors are likely to improve the chances for an innovation to diffuse internationally (4).

The framework can be used for analysing the effects of policies and actors on the adoption and international diffusion of innovations. Its advantage over former studies on environmental regulations (as e.g. Blazejczak et al., 1999) is that it includes the rationale of an international diffusion of innovations. In the next section we will use the concept of lead markets for two cases, fuel-efficiency of passenger cars and wind energy. In both cases lead markets can be identified that were the first to adopted innovations that could later be exported, and strengthened the competitive advantage of the country in the wind generation and car industry considerably. We discuss what regulations have been used and what were the reasons for the international success of the innovations induced by those.

\section{Case studies}

\subsection{Fuel-efficient Passenger Cars}

Fuel-efficiency is a mean to lower the emission of gases that are harmful or cause the greenhouseeffect. Fuel-efficient passenger cars are cars that consume a low level of fuel per $100 \mathrm{~km}$. They are powered by gasoline, hydrogen or they are equipped with both gasoline and electric engines (hybrid cars). In Germany, the most fuel efficient car is the so called "3-Liter-Auto", which means that they consume less than 4 litres per $100 \mathrm{~km}$. In the 1990s this limit was a realistic goal for most car manufacturers in the context of the European driving habits and design preferences, so that policies, such as favourable tax treatment, were introduced to support it. At the end of the 1990s, there are several German car models that are within this low consumption limit.

Modern fuel-efficient passenger cars use a bundle of technologies that are aimed at reducing the fuel consumption of a car. The most effective technologies to reduce fuel consumption are the use of lowweight materials, the sharpening of the aerodynamics of the car body and perfecting of the combustion process. The last approach has been the most frequently used path of technical development, partly because it is the most efficient, partly because of market preferences. In fact, cars have become even 
heavier over the time and the body design has to follow safety, as well as aesthetic criteria (Franke, 1998). Among the motor technologies, the high-pressure direct injection has been most successful in the 1990s. The most successful is the high-pressure fuel injection or common-rail injection system. High-pressure injection improves the combustion, lowers the emission of exhaust gases and at the same time increases the performance, notably the acceleration of cars. In diesel engines the highpressure injection became almost a standard during the 1990s (Figure 4). The modern injection systems were developed by several car companies in Europe and Japan. Germany, however, was the lead market. The US and Japanese markets lagged this technical change, since the share and reputation of diesel powered cars are much lower there (Petersen and Diaz-Bone, 1998).

\section{Figure 4: International Diffusion of Diesel-High-pressure-injection}

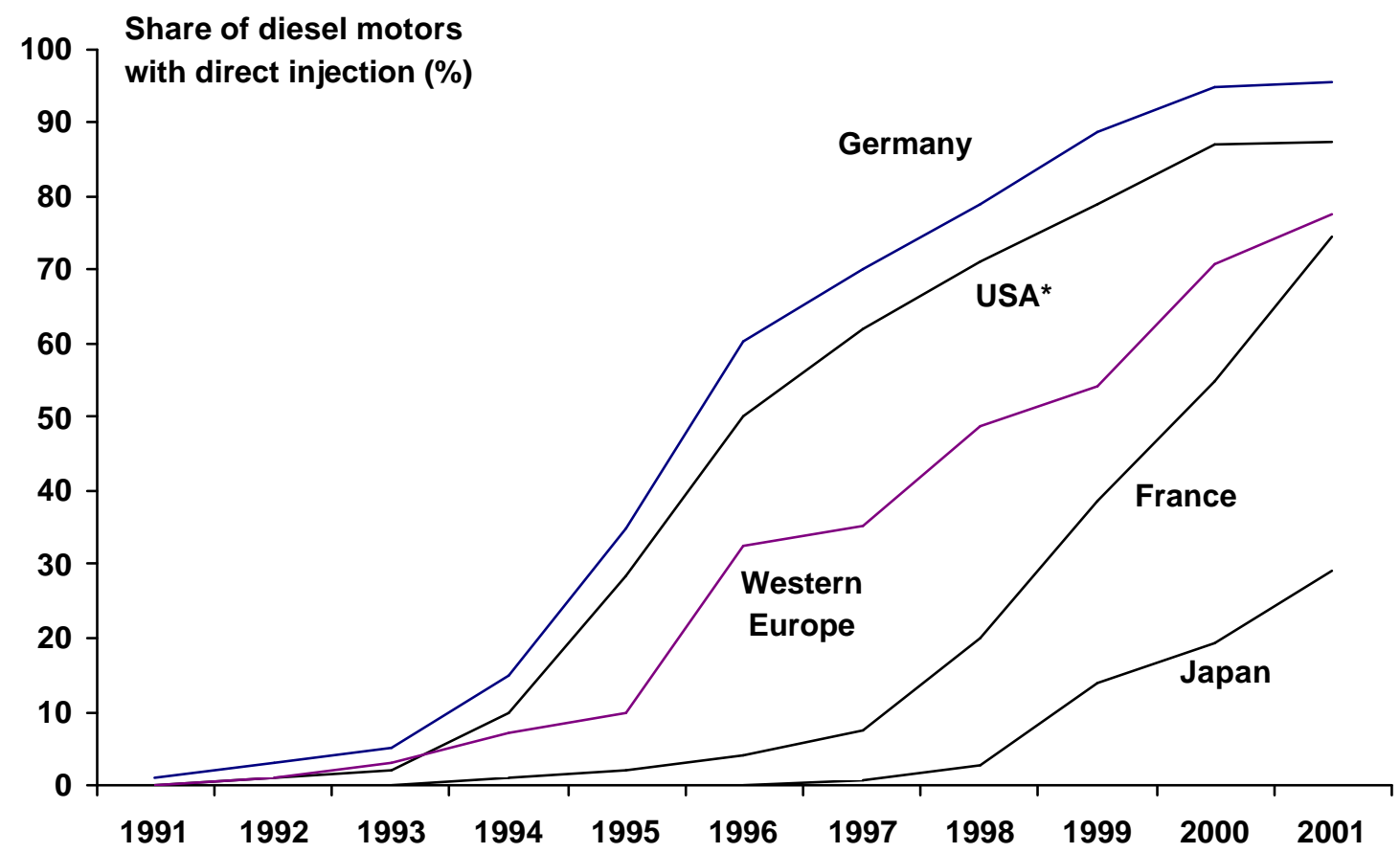

Source: ZEW, Bosch

* USA: predominantly light trucks

There are only few policy instruments in the car industry that directly stipulate the fuel consumption of cars. Only the US introduced in 1975 a fuel economy rule (CAFE) for new cars. It requires each company, selling cars in the US, to reach a minimum of the average consumption of all cars sold in one year of 8.77 litre per $100 \mathrm{~km}$. This rule has not been adopted in other countries so far. In Europe, a voluntary fleet consumption reduction plan by the European Automobile Manufacturers Association prevented its establishment into legislation. One of the reasons why this regulation has not been diffused internationally is, that it proved not to be effective. The main weakness is that this regulation does not affect demand. First, car firms can violate the rules and pay fines, if demand favours more 
fuel-inefficient car designs. Second, there is a loophole in the rules that coincided dramatically with a market trend in the US. Light trucks that became the most successful models in the US were granted a much higher limit (11.63 litres per $100 \mathrm{~km}$ ). Light trucks now account for more than $50 \%$ of all sales and consume $41 \%$ of the oil used. The effect of CAFE on fuel consumption was therefore low or even negative, since the share of light trucks increased dramatically. US cars still have the highest fuel consumption in the world. There are very little incentives for users to buy fuel-efficient cars. That means that there is no demand for fuel efficiency and no incentive for car producers to lower average fuel consumption below the threshold (Bommer, 1996).

Legislation in the car industry is mainly aimed at reducing exhaust gases from passenger cars. The specific regulations however vary from country to country. These differences in regulation have the effect, that different engine technologies are efficient for keeping the limits of emission. In the United States policies are much more aimed at reducing the harmful exhaust emission gases such as $\mathrm{NO}_{\mathrm{x}}$, while in Europe the regulation is concentrated on $\mathrm{CO}_{2}$, the gas responsible with the greenhouse effect. Since $\mathrm{CO}_{2}$ is equivalent to the volume of fuel, a reduction of $\mathrm{CO}_{2}$ is only possible through higher fuelefficiency of the motor. $\mathrm{NO}_{\mathrm{x}}$ on the other hand can be reduced by catalytic converters and improved combustion processes without reducing the fuel consumption. The European regulation therefore $d-$ rectly pressures for higher fuel efficiency of cars. Another effect of these differences is, that the diesel engine technology was boosted by the European legislation, while the US rules are detrimental to the adoption of diesel cars. Diesel engines today are the most economic combustion motors. The limit of three litres fuel per $100 \mathrm{~km}$ are only made possible with modern diesel technology. However, diesel engines have a higher $\mathrm{NO}_{\mathrm{x}}$ emission than comparable gasoline engines. Diesel engines are therefore not an attractive technology for US car manufacturers that aim to follow the US emission rules with as little $R \& D$ as possible. Yet, for diesel engines are the most promising technology to reduce fuel consumption in the short term, European car manufacturers have concentrated a lot of R\&D effort on refining diesel engines so that they managed to reduce not only $\mathrm{CO}_{2}$, but $\mathrm{NO}_{\mathrm{x}}$ as well.

What factors made fuel-efficiency innovations being adopted in Europe more internationally successfully? Europe has the highest fuel prices in the world, making fuel-efficient innovation most beneficial there. Yet, while there is a global trend of increasing gasoline prices, the differences, especially between some European states and the US are still so large, that fuel-efficiency alone cannot persuade US users to adopt the innovation. Only those innovations diffused internationally that not only reduce consumption, but also enhanced other attributes of a car that lay in the global demand trend of passenger cars. Another global trend is at work. Over the time, cars become more luxurious, heavier and powerful. Fuel-efficient technologies were needed to prevent the consumption levels to increase. In addition to its fuel efficiency feature, high-pressure direct injection proved to be a large improvement for diesel engines, that suffered from low acceleration performance. The main reason for the international success was neither the fuel-efficiency legislation, nor the other environmental factors that make fuel-consumption more economical. Fuel efficiency technologies become international successful that 
are compatible with the demand preferences in all major markets. Small or microcompact cars are successful in Japan or Parts of Europe, in large countries like the US they probably will never be. High pressure injection is not only used in 3 Liter cars but for all types of cars even for large luxurious ones and Diesel engines are more likely to become successful worldwide.

This explains, why several innovations, that only optimised environmental criteria but did not meet other consumer demands with higher priority, such as driving power, failed. A good example is the Golf Ecomatic that was developed by Volkswagen and was introduced to the market in 1993. The Golf Ecomatic switched automatically the motor off when it was not in use, e.g. when the lights are red, starting it again when a gear is used. This lead to a substantial reduction of fuel consumption between 20 and 25 percent, especially in urban traffic. The innovation won several environmental awards, but only 3,000 vehicles were sold in total on the market (Petersen/Diaz-Bone 1998). The driving behaviour of the Gold Ecomatic seemed somehow strange for drivers. Volkswagen introduced another new Golf version nearly at the same time, a Diesel-High-pressure-injection model, being not only fuel-efficient but offering also increased driving-power. The so-called "Golf Turbo Diesel" became very successful.

\subsection{Wind Energy}

The world market for renewable energies and especially wind energy has increased rapidly over the past decades, further lifted by oil crises and the following discussion of environmental impacts of fossil fuels. The developing world market is dominated by the small Nordic country of Denmark. Denmark is the pioneer country of electricity production by wind. Although Germany is the country with the largest wind energy capacity installed in the world, the usage of wind energy as a share of total wind potential is still smaller than in Denmark. Figure 5 shows the penetration rate of wind energy use in different countries and identifies Denmark as lead market. Germany follows closely while other countries are developing wind energy with a considerable lag. The penetration rate has been measured as the percentage of exploitation of on-shore wind potential. We have used also other possible indic ators, as e.g. the share of wind energy of total electricity production, leading to the same result. 


\section{Figure 5: International Diffusion of Wind Energy}

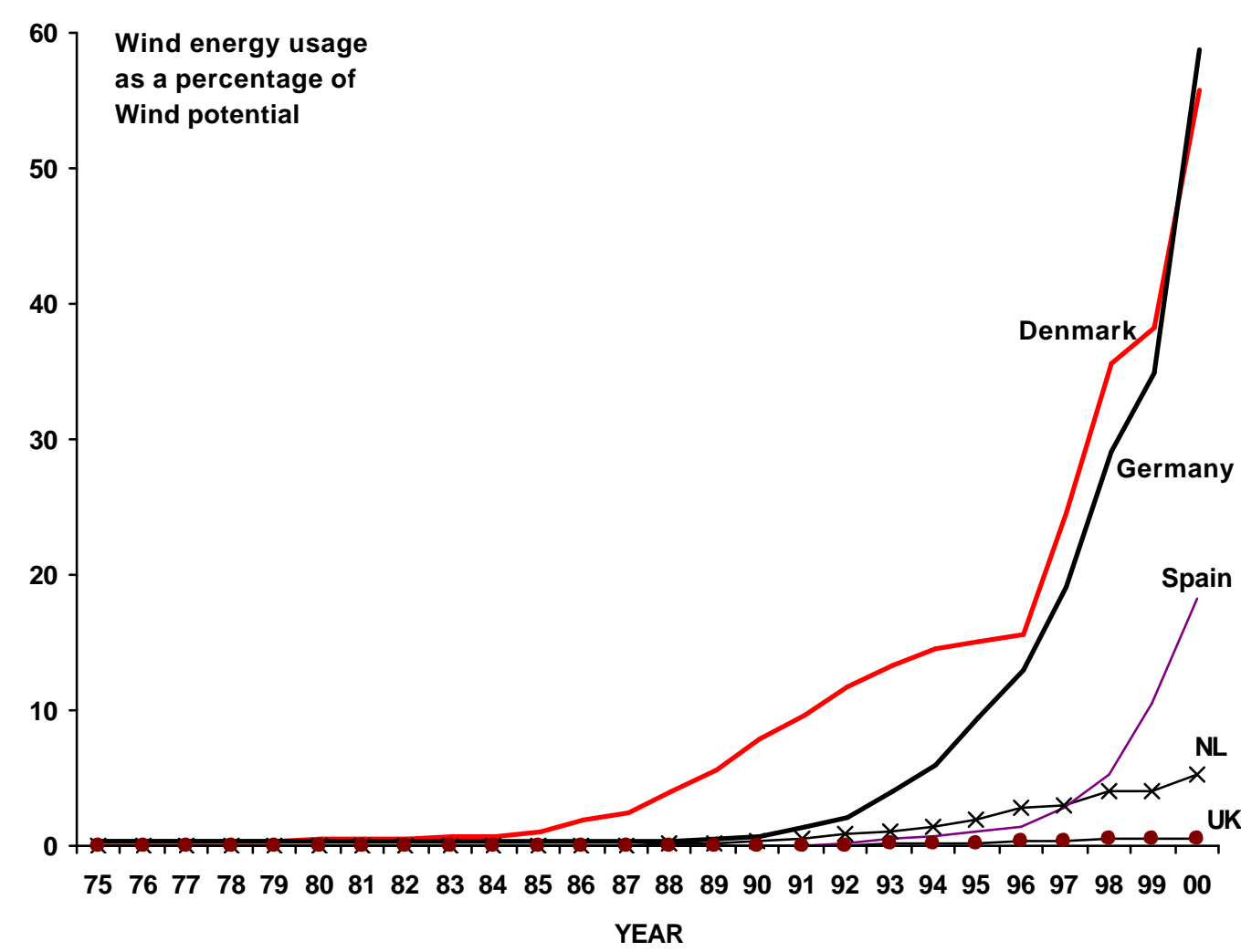

Source:

Source: OECD, LEHMANN, REETZ (1995)

As a consequence of its leading role in using wind energy, Denmark is the worlds largest exporter of wind turbine generators. When import- and export markets of the two countries are compared, it can be seen that Germany exports only a small part of its wind turbines to other countries (BTM-Consult 2002). While Denmark's wind industry is world market oriented, the German wind industry depends more on domestic demand and regulation (Denmark: 81\% exports, 19\% imports; Germany: 10\% exports, $90 \%$ imports).

Denmark looks back to a long history, regarding the technical development of wind mills. In 1918 already, 120 Danish energy utilities had a wind mill with a typical size of 20 to $35 \mathrm{~kW}$, providing 3 percent of the total electricity production in Denmark. The so-called "Danish Concept" is traditionally characterised by three rotor blades. Since the fifties direct current generators plants were replaced by generators producing alternating current (modern types of these generators are asynchronous generators). Also the third typical feature of modern wind energy converters was already developed before the oil crisis: today, the converting systems are equipped with pitch or active stall regulations. Both mean different techniques for increasing the flexibility concerning changing wind forces.

While wind energy was seen as being too expensive to compete with fossil fuels, the situation changed during the oil crisis. Several countries began to install big wind power plants with 1 Megawatt and 
more, like the GROWIAN in Germany. They, however, failed since they were economically inefficient. The main criteria for the technological development of such large wind power plants was their compatibility with the existing system of large, centralised fossil and nuclear energy plants. Energy utilities had no incentives to undermine their own system by developing a decentralised alternative system of renewable energies. In contrast, the technological trajectory of wind energy in Denmark was characterised by more variety and flexibility (Heymann 1995). Although some experiments with large wind power plants were undertaken, the industrial and economic breakthrough was achieved by the continuos improvement of smaller converters. The 55 Kilowatt generation of wind turbine generators being developed between 1980 and 1981, realised cost reductions of about 50 percent. In the 80s many technology support programmes were set up all over the world, e.g. in California. Thousands of Danish Micon 55 Kilowatt wind turbines were exported to Palm Springs. The Danish producers had the first mover advantage. They had started with the industrial production of wind turbines five years earlier than their competitors (Danish Wind Industry Association, 2002). Since the 80s the size of wind turbines is increasing continuously. The diameter of new rotor blades increased from 23 meters in 1990 to 44 meters in 1993 and 63 meters in 1997. Modern generators have already passed the Megawatt class of the GROWIAN generation. In the year 2000, 15 plants had an installed capacity of 2 Megawatt and more. Offshore generators are planned with 3 to 5 megawatt (Institute for Solar Energy Technology, 2002).

Policies for wind energy usage rather varied from country to country. In Europe, three different types of strategies supporting wind energy can be observed (Langraf and Kellner 2000, Haas 2001, BTMConsult 2002):

- Renewable Energy Feed Tariffs (REFITs),

- $\quad$ Bidding systems and

- Tradable permit system for renewables.

Some countries have implemented systems with additional incentives, such as tax reductions or specific depreciation privileges for renewable energies.

Renewable Energy Feed Tariffs (REFITs) have been implemented in Germany, Denmark, Spain, Italy and Austria. Temporarily they have also been used in Ireland (until 1994) and the Netherlands (until 1995), recently they have been also introduced in France (in 2001). In 2000 Denmark has switched to a quota system. The REFITs system introduces fixed prices for green electricity, which have to be paid by energy utilities to producers of renewable energy. Thus, the system can be characterised as a subsidy for wind energy. The REFITs system is criticised, since it is in conflict with the current trend of liberalised energy markets. The main advantage is the low risk for investors, which has lead to a wind energy boom in countries with REFITs systems. On the other hand this is also a disadvantage, since 
the competitive pressure on producers is low, too. This may lead to a system with higher costs of wind energy compared to a more competitive system.

Bidding systems have been implemented in the United Kingdom and, since 1995, also in Ireland. Temporarily they have also been used in France (until 2001). Competition among electricity producers is created by calls for tender from an agency representing the government. Energy utilities have the obligation, to buy a fixed amount of renewable energy per year from different sources. The quantity is defined by the authority, and suppliers with the lowest price are selected to produce it. Energy utilities are compensated for additional costs by a national duty on energy, which has to be paid by all energy consumers. The bidding system leads to high competitive pressure, low costs and prices. Average wind energy prices in Germany were 1997 twice as high as in the United Kingdom. In the bidding system, only the best wind locations have a change to succeed, if at all, while the prices of the REFITs system are higher since they are oriented on estimated average costs of wind energy. The problem of bidding systems is a high risk for investors, which is strengthened by an application process, often characterised as being expensive, time-consuming and bureaucratic. A further problem is the lack of continuity since the bidding conditions often change. Consequently no remarkable wind industry could be established in any country with bidding systems.

Systems of green tradable permits for renewable energies have been introduced up to now only in the Netherlands. Denmark has switched from the REFITs system to a system of quotas in 2000, intending that the quotas become tradable. Tradable permits combine the efficiency gains of bidding systems with the advantages of REFITs systems (reaching environmental goals by fixed targets concerning the development of renewable energies). The state defines quotas for renewable energies and emits certificates to firms producing the desired kind of green energy. The certificates can be traded on the market. Energy utilities are obliged to hold a certain percentage of renewable energy in their portfolio, i.e. they have to decide if they buy a certain amount of certificates for renewables on the market or if they produce green electricity themselves.

Substantial differences can be identified when the regulation systems are related to development of a national wind industry (Haas 2001). In countries with REFITs system wind industry developed rapidly, for instance in Denmark, Germany, Italy, Austria and Spain, until 1994 and 1995 also in Ireland and the Netherlands. In countries with bidding systems wind energy use developed very slowly, independent of the existing wind resources. In France, United Kingdom and Ireland wind industry is poorly deve loped although coastal regions with high wind potentials exist.

Finally, the system of tradable permits for green electricity is still too young to evaluate the impact on the wind industry. It can be expected that the success will depend heavily on the design of the trading system and of the underlying quota system. The European Commission has formulated the ambitious goal of doubling the share of renewable energy within 10 years until 2010 (Jung 2002). If the system of tradable quotas is based on such ambitious goals, it may lead to a very dynamic development of 
wind industry and wind energy technologies. If the quotas are less ambitious, the development of wind industry may break down. Denmark has experienced such a break down in 2001 after switching from the REFITs system to the quota system. In 2001 only 117 MW new wind capacity were installed in Denmark, compared to 802 MW in Spain and 2,659 MW in Germany (BTM Consult 2002).

\section{Conclusions}

In the final section we draw some conclusions concerning the relevance of our identified lead market factors for the two cases.

Price advantages seem to be a relevant but not the dominating driver of the international diffusion of the innovation in both cases. In the case of fuel-efficient cars, high prices for small 3 litre cars are still a substantial bottleneck for their success. Lower prices for Diesel compared to petrol in Germany and France has increased the market share of Diesel cars in these countries, reaching a share of 25 and 50 percent respectively. This is, however, no global trend yet. In the case of wind energy it can be stated that renewable energies are still more costly compared to conventional energy sources such as fossil fuels or nuclear energy. Since renewable energies produce fewer external effects, regulatory measures are needed for internalisation. Experience shows that REFITs systems were most successful concerning internalisation of external effects (subsidies for environmental friendly energy sources), production of renewable energy at reasonable prices and development of a competitive domestic wind industry. Obviously protected niche markets are needed at least temporarily to create an attractive environment for investments into alternative energy plants. In contrast, bidding systems led to cost reductions but also to uncertain and risky investment conditions. No country with bidding systems could reach an substantial share of the wind energy world market. The different experience of policies leads to a policy convergence favouring the REFITs system as the most successful and globally dominating policy.

Demand advantages are crucial for the lead market of fuel-efficient cars since other criteria of global demand are still more important than environmental criteria. People demand fuel-efficient cars only if they meet performance criteria additionally to ecological criteria with no, low or even negative costs. Negative costs can occur due to lower fuel consumption of eco-efficient cars. Thus fuel-efficient cars can be subsumed under Case A in section 3.1. This explains the success of the Diesel-High-pressuredirect-injection technology. Reductions of fuel consumption over the past 30 years have nearly been compensated by heavier and more powerful cars. Since there is no real world market for small 3 litre cars, especially not in the US, only innovations that offer additional benefits and anticipate consumer's demand trends diffuse world-wide. Fuel-efficient technologies are employed not only in small or micro compact cars, the prototype of a fuel efficient car, but also in large luxurious cars such as Mercedes-Benz. Those cars are internationally more successful than any other type and it can be expected that the most successful fuel-efficient car will rather be a midsize sedan than the 3-litre cars currently offered. In the case of wind energy consumer's demand trends are less important. Electrical energy is a 
homogeneous product and most consumers do not care which energy source they get the electrical energy from (a typical example of Case B as described in section 3.1). It is more important for lead markets to anticipate trends of global environmental problems. Denmark as the lead market of wind energy has anticipated this global trend towards alternative energy resources early. The context of the Danish market then facilitated the development of energy generation that could be exported.

Transfer advantages can be identified in both cases since the R\&D activities of the German automobile firms and the respective efforts of the Danish wind industry are intensively watched by other countries. The innovations have to prove their feasibility and practicability in daily life before they diffuse internationally. In the fuel efficiency case it is an obstacle for radical innovations like hybrid cars or fuel cells to prove practicability because they require substantial changes of driving habits or infrastructure etc. Thus incremental innovations as the Diesel-High-pressure-direct-injection are preferred. Geographical and regulatory characteristics of the US automobile market are an obstacle for small 3 litre cars and Diesel engines. In the case of renewable energies radical innovations like wind energy have somehow better chances since they do not require any changes of consumer behaviour. Bottlenecks are higher costs and compatibility with the existing energy system (including infrastructure and conflicts with lobbyists of conventional energy sources).

Export advantages address the similarity of market conditions at home and abroad. They are more important in the wind energy case than for fuel-efficient cars. Wind turbine technologies are very similar all over the world, creating substantial transfer advantages for exporting countries. Denmark produced a large share of the wind turbines which were installed in the US. They were identical with the domestic installations.

Finally the market structure or Porter effect has proved to be relevant in both cases. In the case of wind energy strict regulation, together with an anticipated regulatory trend as described above, can be seen as the dominating success factor for Denmark as a lead market. Without strict regulations and international policy diffusion renewable energies would not be competitive. For fuel efficient cars the Porter effect is less important since environmental regulation is to date still outweighed by consumer preferences that steer diametrically into the opposite direction.

Summing up, all lead market factors seems to be at least relevant for environmental innovations. The importance of the Porter effect depends on its relation to global demand and regulatory effects. If national regulation is supported by global demand or regulatory trends, a strong effect can be identified, as was shown in the cases of wind energy in Denmark and Diesel-High-pressure-direct-injection in Germany. If it is not supported, the market remains idiosyncratic, as could be seen in the failure of the the Golf Ecomatic. 


\section{References}

Audretsch, D., 1995. Innovation and Industry Evolution. Cambridge, MIT Press.

Baumol, W., J. Panzar, R. Willig, 1982. Contestable Markets and the Theory of Industry Structure. New York: Harcourt Brace Jovanovich.

Beise, M., 2001. Lead Markets: Country-specific Success Factors of the Global Diffusion of Innovations, ZEW Economic Studies, Vol. 14, Heidelberg, Physica.

Bennett, C. J., 1991. Review Article: What is Policy Convergence and What Causes it? British Journal of Policy Studies 21, $21-233$.

Bennett, C. J., 1997. Understanding Ripple Effects: The Cross-National Adoption of Policy Instruments for Bureaucratic Accountability, Governance 10 (3), 213-233.

Blazejczak, J., D. Edler, J. Hemmelskamp and M. Jänicke, 1999. Environmental Policy and Innovation - An International Comparison of Policy Patterns and Innovative Impacts. In: P. Klemmer (Ed.): Innovation and the Environment, Analytica, Berlin, 9-30.

Bommer, R., 1996. Das Drei-Liter-Auto: Ein sinnvoller Lösungsansatz? Wirtschaftsdienst 1996/V, 256-260.

BTM Consult, 2002. BTM statistics, http://www.btm.dk

Cooper, R. G. and E. J. Kleinschmidt, 1987. Success factors in product innovation, Industrial Marketing Management 16, 215-223.

Dekimpe, M. G., P. M. Parker and M. Sarvary, 1998. "Globalisation”: Modelling Technology adoption Timing across Countries, INSEAD working paper No. 98/69/MKT.

Danish Wind Industry Association, 2002. Windpower Information, http://www.windpower.dk

Dolowitz, D. and D. Marsh, 1996. Who Learns What from Whom: a Review of the Policy Transfer Literature, Political Studies 44, 343-357.

Dosi, G., K. Pavitt and L. Soete, 1990. The Economics of Technical Change and International Trade, New York, Harvester Wheatsheaf.

Ebling, Günther and Norbert Janz, 1999. Export and Innovation Activities in the German Service Sector: Empirical Evidence at the Firm Level, ZEW Discussion Paper No. 99-53, Mannheim.

Franke, A., 1998. Auf dem Weg zum 3-Liter-Auto - Minderung der verkehrsbedingten CO2-Emissionen, Ifo Institut, Abschätzung der innovativen Wirkungen umweltpolitischer Instrumente - dargestellt am Beispiel des Systems Straßenverkehr, München, 146 - 179.

Franko, L. G., 1976. The European Multinationals, London, Harper \& Row.

Haas, R. (Ed.), 2001. Promotion Strategies for Electricity from Renewable Energy Sources. Institute of Energy Economics, Vienna University of Technology

Hemmelskamp, J., K. Rennings and F. Leone (2000). Innovation-oriented Environmental Regulation: Theoretical Approaches and Empirical Analysis. Heidelberg, Physica.

Heymann, M., 1995. Die Geschichte der Windenergienutzung 1890-1990, Frankurt, Campus.

Hills, J., 1986. Deregulating Telecoms: Competition and Control in the United States, Japan and Britain, London, Pinter.

Hippel, E. v., 1988. Sources of Innovation, New York, Oxford University Press.

Institute for Solar Energy Technology (ISET), 2002. Renewable Energy Information System on Internet - REISI. http://reisi.iset.uni-kassel.de

Jaffe, A. B., R. G. Newell and R. N. Stavins, 2002. Environmental Policy and Technological Change. Environmental and Resource Economics 22, 41-69.

Jänicke, M., 2000. Ökologische Modernisierung als Innovation und Diffusion in Politik und Technik: Möglichkeiten und Grenzen eines Konzepts, Forschungsstelle für Umweltpolitik Report 00-01.

Jung, A., 2002. Rahmenbedingungen für die Nutzung erneuerbarer Energien. Paper presented on the Conference "Renewable Energies" in Wiesbaden, August 28 and 292002.

Kalish, S., V. Mahajan and E. Muller, 1995. Waterfall and Sprinkler New-Product Strategies in Competitive Global Markets, International Journal of Research in Maketing 12, 105-119. 
Kern, K., H. Jörgens and M. Jänicke, 2000. Die Diffusion umweltpolitischer Innovationen: Ein Beitrag zur Globalisierung von Umweltpolitik, Zeitschrift für Umweltpolitik \& Umweltrecht (4), 507-546.

Klemmer, P. (Ed.), 1999, Innovationen und Umwelt, Innovative Wirkungen umweltpolitischer Instrumente, Bd. 3, Berlin. Analytica.

Langraf, B. and T. Kellner, 2000. Windenergie in Europa: Was bringen Gesetzgebung und Fördermaßnahmen, Interwind AG, im Auftrag des Bundesamtes für Energie (Ch), Zürich.

Lehmann, H., T. Reetz , 1995. Zukunftsenergien - Strategien einer neuen Energiepolitik. Basel

Levitt, T., 1983. The Globalisation of Markets, Harvard Business Review 61 (3), 92-102.

Linder, S. B., 1961. An Essay on Trade and Transformation, Uppsala, Almqvist \& Wiksells.

Lundvall, B.-Å., 1988. Innovation as an Interactive Process - from User-Producer Interaction to the National System of Innovation, in: G. Dosi et al. (Eds.), Technical Change and Economic Theory, London, Pinter, 349-369.

Majone, G., 1991. Cross-National Sources of Regulatory Policy Making in Europe and the United States, Journal of Public Policy 11, 79-106.

Mansfield, E., 1968. Industrial Research and Technological Innovation: An Econometric Analysis, New York, Norton.

Mowery, D., R. Nelson, 1999. Introduction, in: Mowery, D. and R. Nelson (eds.), Sources of Industrial Leadership, Cambridge, Cambridge University Press, 1-18.

OECD, 2000. Innovation and the Environment. Paris.

Peters, G., 1997. Policy Transfer Between Governments: The Case of Administrative Reform, West European Politics 20, 7188.

Petersen, R and H. Diaz-Bone, 1998. Das Drei-Liter-Auto, Berlin, Birkhäuser Verlag

Porter, M., H. Takeuchi, M. Sakakibara, 2000. Can Japan Compete? London.

Porter, M. E. and C. van der Linde, 1995., Towards a New Conception of the Environment-Competitiveness Relationship, Journal of Economic Perspectives 9 (4), 97-118.

Porter, M., 1990. The Competitive Advantage of Nations, Free Press, New York.

Posner, M. V., 1961. International Trade and Technical Change, Oxford Economic Papers 30, 323-341.

Rennings, K., 2000. Redefining Innovation - Eco-Innovation Research and the Contribution from Ecological Economics, Ecological Economics 32, 319 - 332

Rennings, K. and T. Zwick, 2002. The Employment Impact of Cleaner Production on the Firm Level - Empirical evidence from a Survey in Five European Countries. In: International Journal of Innovation Management (IJIM), Special Issue on „The Management of Innovation for Environmental Sustainability“, Vol. 6, No. 3, pp.319 - 342.

Richardson, J. (Ed.), 1982. Policy Styles in Western Europe, London.

Rose, R., 1993. Lesson-Drawing in Public Policy: a Guide to Learning Across Time and Space, Chatham, New Jersey, Chatham House.

Sonnenfeld, D. A., 2000. Contradictions of Ecological Modernisation: Pulp and Paper Manufacturing in South-east Asia, in: Mol, A and D. Sonnenfeld (Eds.), Ecological Modernisation Around the World: Perspectives and Critical Debates, London, Portland, OR: Frank Cass, 235-256.

Takada, H. and D. Jain, 1991. Cross-National Analysis of Diffusion of Consumer Durable Goods in Pacific Rim Countries, Journal of Marketing 55, April, 48-54.

Tilton, J. E., 1971. International Diffusion of Technology: The Case of Semiconductors, Washington, D.C., The Brookings Institution.

Utterback, J. M., 1994. Mastering the Dynamics of Innovation, Boston, Harvard Business School Press.

Vernon, R., 1966. International Investment and International Trade in the Product Cycle, Quarterly Review of Economics 88, May, 190-207.

Vernon, R., 1979. The Product Cycle Hypothesis in a New International Environment, Oxford Bulletin of Economics and Statistics 41 (4), 255-267. 